\title{
CICLO DA VIDA INY (KARAJÁ)
}

\section{Leandro Lariwana Karajá \\ Professor Pesquisador}

\section{RESUMO}

Toda organização do povo Iny está relacionada com o ciclo da natureza e a crença do mundo espiritual existente no céu, na água, e nas matas. A educação do povo Iny é especial em cada ciclo da vida. Esta forma de educação existe entre nós Karajá, começando desde o nascimento, até a fase adulta, e, no decorrer desse tempo, o aprendiz recebe vários tipos de saberes tradicionais de seus familiares e da própria comunidade, o que veremos mais para frente.

PALAVRAS CHAVE: Educação formal Karajá. Saberes tradicionais. Ciclo de vida.

\section{TURYBÈBUTÈ}

Iny bdèdỹỹnana tiièmy suu biu bdèdỹỹnana-ò hyy rexilòròmyhỹre tai hyy ròwèrymyhỹre, tyytby biu-my rỹira, bè-my tule bjiu-my. Tai tahè iny dohodỹỹnanahè irbi namyhỹde, iny tohouã-my ròhònymyhỹrerbi raòrarumyhỹre tuhyy tahè iny raumynymyhỹre. Iykyki tahè sõèmy uladu dohodỹỹna òtaòta-my ratohodỹỹnymyhỹre, tasỹrènyrbi tule tahãwarènyrbi, idi wiji rkètèhèrènykre tako-ò.

RYBÈ WẼRYNA: Iny dohodỹỹnatyhy. Iny bdèèry. Iny umyna wèrymy.

A organização do povo INY sempre está relacionada com o ciclo da natureza e a crença do mundo espiritual existente no céu, na água, e nas matas. Assim, o ciclo da vida é uma forma de educação que existe entre nós Karajá, começando desde o nascimento, até a fase adulta, e, no decorrer desse tempo, o aprendiz recebe vários tipos 
de saberes tradicionais de seus familiares e da própria comunidade, $\mathrm{o}$ que veremos mais para frente.

\section{NASCIMENTO}

O nascimento biológico tem a ver com os recém nascidos, que geralmente são pintados com a tinta vermelha do urucum, da cabeça aos pés, de ambos os sexos. Isso simboliza o nascimento biológico. Nessa fase da vida, a criança já começa a ter a primeira educação, que seria o amor e o cuidado da família. Nos primeiros meses, mais ou menos até seis meses de idade, a criança não recebe nenhum tipo de alimento a não ser o leite materno. Depois que completa seis meses, a família faz uma pequena cerimônia para ensinar a criança a comer outros tipos de alimentos. Aqui entra a educação alimentar e os princípios higiênicos que seguem a vida da criança, do nascimento e para todo o sempre.

Quando a criança começa a falar, os familiares se responsabilizam para ensinar a linguagem padrão do Iny Rybè, mostrando a ela a diferença entre a fala masculina e a feminina, caso contrário, a menina aprenderia a falar na fala masculina e o menino na fala feminina, tudo na oralidade do dia a dia da família.

Junto dessa primeira educação, entram os principais fundamentos da educação do povo Iny, a responsabilidade, o respeito, a humildade e a generosidade. Tudo isso é muito importante para que a criança seja preparada para a vida, aprendendo a respeitar qualquer indivíduo, principalmente os pais. A falta desse tipo de educação pode tornar a criança ignorante, sem amor pelos outros ou até mesmo pela própria vida. Tudo que os familiares fizerem será assimilado pela criança.

Em torno de 11/12 anos, se for menino, o pai pede ao chefe cultural para realizar o ritual de Hetohoky, que dura quase um ano para terminar. No final a criança é levada para dentro do Hetohokỹ, para receber outro tipo de educação, a do mundo espiritual. Neste período, os meninos deixam de ser criança e se tornam Jyrè. Este se torna o correio dos homens. Tudo que os homens pedirem ao menino, ele fará sem reclamar. Assim mostra que ele respeita as pessoas e que é capaz de realizar o trabalho solicitado. Quando se 
torna jyrè, o menino é pintado com a tinta preta, indicando o novo nascimento, o nascimento social, e a cabeça dele é raspada.

Depois que o cabelo cresce, o menino se torna Bòdu, e tem sua própria pintura, conhecida como pintura de pica-pau. Depois dessa fase, se torna Weryrybò. Ao chegar a esta fase, o menino já aprendeu muitas coisas, como, por exemplo: hylòi, latxi, inarèhè, as principais ferramentas de saberes para o resto da vida.

A menina também passa por fases da vida, mas não como o menino. Depois do seu nascimento biológico, a menina só tem três fases: hirari, hirarihiky e ijadoma. Nessas fases, a menina aprende tudo sobre o trabalho doméstico, da mesma forma como o homem aprende tudo isso para sobreviver e para passar para a próxima geração.

Infelizmente, hoje em dia, toda essa educação está acabando e o desaparecimento desse conhecimento ajuda a língua também a desaparecer. Aos poucos o conhecimento do ocidente vem nos dominando. Mas, em contrapartida, estamos lutando ao introduzir dentro do currículo das escolas indígenas o sentimento do valor e da manutenção dos nossos conhecimentos. A meta é mudar a história da colonização dos nossos saberes e retomar o que foi esquecido ao longo dos tempos. A 'Ação Saberes Indígenas na Escola' coloca em nós indígenas essa esperança de construir um novo modelo de escola. 